\title{
AGRIBISNIS SEBAGAI LANDASAN PEMERATAAN PEMBANGUNAN DI KABUPATEN BURU
}

\author{
PENDAHULUAN
}

\section{A. Latar belakang}

Kabupaten Buru dibentuk dengan Undang-Undang Nomor 46 Tahun 1999 tanggal 12 Oktober 1999 tentang Pembentukan Propinsi Maluku Utara, Kabupaten Buru dan Kabupaten Maluku Tenggara Barat sebagaimana telah diubah dengan Undang-Undang Nomor 6 Tahun 2000 tentang perubahan atas undang-undang nomor 46 Tahun 1999 tentang Pembentukan Provinsi Maluku Utara, Kabupaten Buru dan Kabupaten Maluku Tenggara Barat.

Secara geografis Kabupaten Buru terletak pada $126^{\circ} 08-127^{\circ} 20$ BT dan $2^{\circ} 25^{\prime}-3^{\circ} 83^{\prime} \mathrm{LS}$, dengan luas wilayah 7.595,58 KM2 dengan batas-batas wilayah sebagai berikut; sebelah timur berbatas dengan selat manipa, sebelah barat berbatas dengan laut seram, sebelah selatan berbatas dengan kabupaten buru selatan dan sebelah utara berbatas dengan laut seram.

Kabupaten Buru memiliki daratan seluas $7.595,58 \mathrm{~km}^{2}$ yang merupakan salah satu pulau dari gugus kepulauan Maluku. Kabupaten Buru telah dicanangkan sebagai lumbung pangan nasional untuk Indonesia Bagian Timur, sesuai dengan Visi Kabupaten Buru yaitu untuk menjadi Sentra Produksi Pertanian Dan Perikanan Menuju Masyarakat Bupolo yang Mandiri, Sejahtera, Demokratis dan Berkeadilan.

Pada awal pemenuhan kebutuhannya, manusia hanya mengambil dari alam sekitar tanpa kegiatan budidaya (farming), dengan demikian belum memerlukan sarana produksi pertanian. Seiring dengan meningkatnya kebutuhan manusia, alam tidak dapat menyediakan semua kebutuhan itu sehingga manusia mulai membudidayakan (farming) secara ekstensif berbagai tanaman, hewan dan ikan untuk memenuhi kebutuhannya.

Sektor agribisnis merupakan sektor ekonomi terbesar dan terpenting dalam perekonomian nasional Indonesia. Sektor agribisnis menyerap lebih dari $75 \%$ angkatan kerja nasional termasuk di dalamnya 21,3 juta unit usaha skala 
kecil berupa usaha rumah tangga diperhitungkan maka sebesar $80 \%$ dari jumlah penduduk nasional menggantung hidupnya pada sektor agribisnis. Peranan sektor agribisnis yang demikian besar dalam perekonomian nasional memiliki implikasi penting dalam pembangunan ekonomi nasional ke depan (Saragih,1997).

Apabila perencanaan pembangunan pertanian dan pelaksanaannya dikelola dengan baik, pembangunan pertanian yang dilaksanakan dengan seksama dapat memperbaiki pendapatan penduduk secara merata dan berkelanjutan. Pada akhirnya, hasil pembangunan tersebut dapat memakmurkan masyarakat Indonesia secara keseluruhan.

\section{TELAAH PUSTAKA}

\section{A. Pengertian dan Ruang Lingkup Pemerataan Pembangunan}

Undang-Undang (UU) No. 17 tahun 2007 tentang RPJPN tahun 20052025, menyatakan bahwa visi pembangunan nasional tahun 2005-2025 adalah: Indonesia yang Mandiri, Maju, Adil dan Makmur. Untuk mewujudkan visi pembangunan nasional tersebut ditempuh melalui delapan misi yang mencakup: (1) mewujudkan masyarakat berakhlak mulia, bermoral, beretika, berbudaya dan beradab berdasarkan falsafah Pancasila, (2) mewujudkan bangsa yang berdaya saing, (3) mewujudkan masyarakat demokratis berlandaskan hukum, (4) mewujudkan Indonesia aman, damai dan bersatu, (5) mewujudkan pemerataan pembangunan dan berkeadilan, (6) mewujudkan Indonesia asri dan lestari, (7) mewujudkan Indonesia menjadi negara kepulauan yang mandiri, maju, kuat dan berbasiskan kepentingan nasional, dan (8) mewujudkan Indonesia berperan penting dalam pergaulan dunia internasional.

Penekanan pertumbuhan ekonomi regional lebih dipusatkan pada pengaruh perbedaan karakteristik space terhadap pertumbuhan ekonomi. Faktor yang menjadi perhatian utama dalam teori pertumbuhan ekonomi regional (Tarigan,2006) : Keuntungan Lokasi; Teori lokasi adalah suatu ilmu yang mengkhususkan analisanya pada penggunaan konsep space dalam analisa 
social ekonomi. Teori lokasi sering kali dikatakan sebagai pondasi dan bagian yang tidak terpisahkan dalam analisa ekonomi regional. Peranan teori lokasi dalam ilmu ekonomi regional sama halnya dengan teori mikro dan makro pada analisa tradisional. Dengan demikian analisa ekonomi regional tidak dapat dilakukan tanpa peralatan teori lokasi.

Aglomerasi adalah pengelompokan beberapa perusahaan dalam suatu daerah atau wilayah sehingga membentuk daerah khusus industri. Aglomerasi merupakan kondisi terkonsentrasinya kegiatan ekonomi kewilayah perkotaan/sekitarnya (Rusli,90:2005). Beberapa sebab yang memicu terjadinya aglomerasi adalah : a. Scale Economic, yaitu semacam keuntungan yang dapat timbul karena pusat pengembangan memungkinkan perusahaan industri yang bergabung didalamnya beroperasi dengan skala besar karena adanya jaminan sumber bahan baku, tenaga kerja dan pasar. b. Localization economies, yaitu terjadi apabila biaya produksi perusahaan dari suatu industri menurun ketika terjadi konsentrasi usaha pada lokasi tertentu. Singkatnya, dengan berlokasi didekat perusahaan lain dalam industri yang sama, suatu perusahaan dapat menikmati beberapa manfaat, antara lain : efisiensi lokasi bagi eksternalitas teknologi, kemudahan akses untuk memperoleh bermacam-macam barang input, kemudahan akan jasa-jasa keuangan (perbankan), dan dapat memanfaatkan secara bersama berbagai fasilitas infrastruktur (jalan, pelabuhan, sarana telekomunikasi, saluran pembuangan, listrik, dan lain-lain) (Baldwin, 2001).

Beraglomerasinya perusahaan dari industri pada lokasi yang berdekatan mendorong penggunaan tenaga kerja bagi industri yang bersangkutan. Localization Economics, merupakan keuntungan yang dapat timbul karena adanya saling keterkaitan antara industri sehingga kebutuhan bahan baku dan pemasaran dapat dipenuhi dengan mengeluarkan ongkos angkut yang minim. c. Urbanization economies, yaitu apabila terjadi biaya produksi dari suatu perusahaan secara individual menurun sebagai akibat peningkatan total output di daerah perkotaan. Dengan kata lain, Urbanization economies timbul karena makin besarnya perekonomian kota yang diakibatkan oleh meningkatnya jumlah penduduk sehingga menyebabkan beragam kebutuhan yang perlu 
dipenuhi oleh industri. Urbanization Economies, yaitu keuntungan yang diperoleh karena fasilitas pelayanan social dan ekonomi yang dapat digunakan secara bersama sehingga pembebanan ongkos untuk masing-masing perusahaan industri dapat dilakukan serendah mungkin.

Karena pada dasarnya aktivitas perekonomian adalah suatu proses penggunaan faktor-faktor produksi untuk menghasilkan output, maka proses ini pada gilirannya akan menghasilkan suatu aliran balas jasa terhadap faktor produksi yang dimiliki oleh masyarakat. Dengan adanya pertumbuhan ekonomi maka diharapkan pendapatan masyarakat sebagai pemilik faktor produksi juga akan turut meningkat. (Susanti, 2000).

Sedangkan faktor yang mempengaruhi teori pertumbuhan ekonomi nasional adalah; Modal. yang meliputi semua bentuk atau jenis investasi baru yang ditanamkan pada tanah, peralatan fisik dan sumberdaya manusia. Lapangan Kerja, yang beberapa tahun selanjutnya dengan sendirinya membawa pertumbuhan angkatan kerja.

Dengan adanya pertumbuhan ekonomi baik secara langsung maupun tidak langsung akan berpengaruh terhadap masalah ketimpangan regional. Ketimpangan dalam pembagian pendapatan adalah ketimpangan dalam perkembangan ekonomi antara berbagai daerah pada suatu wilayah yang akan menyebabkan pula ketimpangan tingkat pendapatan perkapita antar daerah (Kuncoro, 2004).

Berbagai penelitian tentang ketimpangan antar daerah telah banyak dilakukan. Kuznets (1954) tercatat sebagai salah satu peneliti awal dalam meneliti kesenjangan. Kuznets meneliti kesenjangan di berbagai negara secara cross sectional dan menemukan pola $U$ terbalik. Kuznets menyimpulkan bahwa pendapatan rata-rata perkapita pada awal perkembangan negara masih rendah, dan tingkat kesenjangan juga rendah. Ketika pendapatan rata-rata naik, maka kesenjangan juga meningkat. Kemudian ketika pendapatan rata-rata naik lebih tinggi, maka kesenjangan akan turun kembali.

Menurut Myrdal (Sukirno, 1985) melakukan penelitian tentang sistem kapitalis yang menekankan kepada tingkat keuntungan bagi suatu wilayah yang memberikan harapan tingkat keuntungan tinggi akan berkembang menjadi 
pusat-pusat perkembangan kesejahteraan. Perbedaan tingkat kemajuan ekonomi antar daerah yang berlebihan akan menyebabkan pengaruh yang merugikan (backwash effects) mendominasi pengaruh yang menguntungkan (spread effects) terhadap pertumbuhan daerah, dalam hal ini mengakibatkan proses ketidakseimbangan.

Irma Adelman dan Cynthia Taft Morris tahun 1973 (di dalam buku Lincolin Arsyad, 1997) menyatakan bahwa faktor penyebab ketimpangan pendapatan di negara sedang berkembang adalah sebagai berikut :

Pertumbuhan penduduk yang tinggi yang mengakibatkan turunnya pendapatan perkapita. Inflasi. Dimana penerimaan pendapatan yang bertambah tetapi tidak diikuti secara proporsional dengan pertumbuhan produksi barangbarang. Ketidakmerataan pembangunan antar daerah. Investasi yang sangat banyak dalam proyek-proyek yang padat modal capital intensive. Rendahnya mobilitas sosial. Pelaksanaan kebijakan industri subtitusi impor yang menyebabkan kenaikan harga-harga barang hasil industri untuk melindungi golongan kapitalis. Memburuknya nilai tukar bagi mata uang negara sedang berkembang dalam perdagangan dengan negara maju sebagai akibat ketidakelastisan barang-barang ekspor dari negara sedang berkembang. Hancurnya industri-industri kerajinan rakyat seperti pertukangan, industri rumah tangga dan lain-lain.

Tambunan (2001) mengemukakan beberapa faktor yang menyebabkan ketimpangan wilayah antara lain; Konsentrasi kegiatan ekonomi wilayah. Semakin tinggi konsentrasi kegiatan ekonomi di wilayah tertentu merupakan salah satu faktor yang menyebabkan ketimpangan pembangunan antar daerah. Alokasi Investasi. Berdasarkan teori Harrod-Domar yang menerangkan adanya korelasi positif antara tingkat investasi dengan laju pertumbuhan ekonomi, dengan kata lain bahwa kurangnya investasi disuatu wilayah akan menyebabkan pertumbuhan ekonomi dan tingkat pendapatan masyarakat perkapita di wilayah tersebut rendah, karena tidak ada kegiatan-kegiatan ekonomi yang produktif.

Tingkat Mobilitas dan faktor-faktor produksi yang rendah antar daerah. Kurang lancarnya mobilitas faktor produksi seperti tenaga kerja dan modal bisa 
menyebabkan terjadinya ketimpangan ekonomi regional. Perbedaan Sumberdaya Alam antar daerah. Dasar pemikiran klasik mengatakan bahwa pembangunan ekonomi di daerah yang kaya sumberdaya alamnya akan lebih cepat maju dibandingkan dengan daerah yang miskin sumberdaya alam.

Perbedaan kondisi demografis antar wilayah. Ketimpangan ekonomi regional juga disebabkan oleh perbedaan kondisi demografis, terutama dalam hal jumlah dan pertumbuhan penduduk, tingkat kepadatan, pendidikan, kesehatan, disiplin masyarakat dan etos kerja. Faktor-faktor ini mempengaruhi tingkat pembangunan dan pertumbuhan ekonomi lewat sisi permintaan dan penawaran.

Kurang lancarnya perdagangan. Kurang lancarnya perdagangan antar daerah juga merupakan unsur-unsur yang turut menciptakan terjadinya ketimpangan ekonomi regional. Ketidaklancaran tersebut lebih disebabkan oleh keterbatasan sarana transportasi dan komunikasi.

\section{B. Pengertian dan Ruang Lingkup Agribisnis}

Pengertian sistem agribisnis Agribisnis merupakan sistem pertanian yang saling terkait mulai dari sistem hulu sampai dengan sistem hilir yang memanfaatkan sumber daya yang ada dengan tujuan mendapatkan keuntungan yang sebesar-besarnya. (Saragih,1997) Industri hulu adalah sektor yang memproduksi alat-alat dan mesin pertanian serta industri sarana produksi yang digunakan dalam proses budidaya pertanian. Sementara industri hilir merupakan industri yang mengolah hasil pertanian menjadi bahan baku atau barang yang siap dikonsumsi atau merupakan industry pascapanen dan pengolahan hasil pertanian.

Agribisnis berasal dari kata Agribusiness, di mana Agri=Agriculture artinya pertanian dan Business artinya usaha atau kegiatan yang menghasilkan keuntungan. Jadi, Agribisnis adalah segala kegiatan yang berhubungan dengan pengusahaan tumbuhan dan hewan (komoditas pertanian, peternakan, perikanan, dan kehutanan) yang berorientasi pasar (bukan hanya untuk pemenuhan kebutuhan pengusaha sendiri) dan perolehan nilai tambah. 
Sebenarnya ada beberapa pendapat ahli mengenai Pengertian Agribisnis itu sendiri, seperti uraian berikut :

1. Pengertian Agribisnis Menurut Asal Kata: Agribisnis berasal dari kata Agribusiness, di mana Agri=Agriculture artinya pertanian dan Business artinya usaha atau kegiatan yang berorientasi profit. Jadi secara sederhana Agribisnis (agribusiness) didefinisikan sebagai usaha atau kegiatan pertanian dan terkait dengan pertanian yang berorientasi profit.

2. Pengertian Agribisnis menurut Soekartawi (1993): Agribisnis berasal dari kata agri dan bisnis. Agri berasal dari bahasa Inggris, agricultural (pertanian). Bisnis berarti usaha komersial dalam dunia perdagangan.

3. Pengertian agribisnis menurut Wikipedia adalah : Agribisnis adalah bisnis berbasis usaha pertanian atau bidang lain yang mendukungnya, baik di sektor hulu maupun di hilir. Penyebutan "hulu" dan "hilir" mengacu pada pandangan pokok bahwa agribisnis bekerja pada rantai sektor pangan (food supply chain). Agribisnis mempelajari strategi memperoleh keuntungan dengan mengelola aspek budidaya, pascapanen, proses pengolahan, hingga tahap pemasaran.

"Dengan demikian agribisnis dapat dipandang sebagai suatu sistim pertanian yang memiliki beberapa komponen sub sistim yaitu, sub sistim usaha tani/yang memproduksi bahan baku; sub sistim pengolahan hasil pertanian, dan sub sistim pemasaran hasil pertanian."

Adapun kelima mata rantai atau subsistem tersebut dapat diuraikan sebagai berikut:

1. Subsistem Penyediaan Sarana Produksi Sub sistem penyediaan sarana produksi menyangkut kegiatan pengadaan dan penyaluran. Kegiatan ini mencakup Perencanaan, pengelolaan dari sarana produksi, teknologi dan sumberdaya agar penyediaan sarana produksi atau input usahatani memenuhi kriteria tepat waktu, tepat jumlah, tepat jenis, tepat mutu dan tepat produk.

2. Subsistem Usahatani atau proses produksi Sub sistem ini mencakup kegiatan pembinaan dan pengembangan usahatani dalam rangka meningkatkan produksi primer pertanian. Termasuk kedalam kegiatan ini 
adalah perencanaan pemilihan lokasi, komoditas, teknologi, dan pola usahatani dalam rangka meningkatkan produksi primer. Disini ditekankan pada usahatani yang intensif dan sustainable (lestari), artinya meningkatkan produktivitas lahan semaksimal mungkin dengan cara intensifikasi tanpa meninggalkan kaidah-kaidah pelestarian sumber daya alam yaitu tanah dan air. Disamping itu juga ditekankan usahatani yang berbentuk komersial bukan usahatani yang subsistem, artinya produksi primer yang akan dihasilkan diarahkan untuk memenuhi kebutuhan pasar dalam artian ekonomi terbuka.

3. Subsistem Agroindustri/pengolahan hasil Lingkup kegiatan ini tidak hanya aktivitas pengolahan sederhana di tingkat petani, tetapi menyangkut keseluruhan kegiatan mulai dari penanganan pasca panen produk pertanian sampai pada tingkat pengolahan lanjutan dengan maksud untuk menambah value added (nilai tambah) dari produksi primer tersebut. Dengan demikian proses pengupasan, pembersihan, pengekstraksian, penggilingan, pembekuan, pengeringan, dan peningkatan mutu.

4. Subsistem Pemasaran Sub sistem pemasaran mencakup pemasaran hasilhasil usahatani dan agroindustri baik untuk pasar domestik maupun ekspor. Kegiatan utama subsistem ini adalah pemantauan dan pengembangan informasi pasar dan market intelligence pada pasar domestik dan pasar luar negeri.

5. Subsistem Penunjang

Subsistem ini merupakan penunjang kegiatan pra panen dan pasca panen yang meliputi :

- Sarana Tataniaga

- Perbankan/perkreditan

- Penyuluhan Agribisnis

- Kelompok tani

- Infrastruktur agribisnis

- Koperasi Agribisnis

- BUMN

- Swasta 
- Penelitian dan Pengembangan

- Pendidikan dan Pelatihan

- Transportasi

- Kebijakan Pemerintah

Peranan agribisnis sebagai suatu sistem dalam pengembangan sektor pertanian di Indonesia; Sektor pertanian memiliki peranan penting di Indonesia karena sektor pertanian mampu menyediakan lapangan kerja, mampu mendukung sektor industri baik industri hulu maupun industri hilir, mampu menyediakan keragaman menu pangan dan karenanya sektor pertanian sangat mempengaruhi konsumsi dan gizi masyarakat. Hal ini ditunjukkan oleh besarnya kontribusi sektor pertanian terhadap Produk Domestik Bruto (PDB) terutama pada masa kirisis ekonomi yang dialami Indonesia, satu-satunya sektor yang menjadi penyelamat perekonomian Indonesia pada tahun 19971998 hanyalah sektor agribisnis, dimana agribisnis memiliki pertumbuhan yang positif.

Peranan agribisnis sektor pertanian misalnya dalam penyediaan bahan pangan. Ketersediaan berbagai ragam dan kualitas pangan dalam jumlah pada waktu dan tempat yang terjangkau masyarakat merupakan prasyarat penting bagi keberhasilan pem-bangunan di Indonesia. Sejarah modern Indonesia menunjukkan bahwa krisis pangan secara langsung mempengaruhi kondisi sosial, politik, dan keamanan nasional.

Pada dasarnya tidak perlu diragukan lagi, bahwa pembangunan ekonomi yang berbasiskan kepada sektor pertanian (agribisnis), telah memberikan bukti dan dan peranan yang cukup besar dalam pembangunan perekonomian bangsa, dan tentunya lebih dari itu. 


\section{ANALISIS DAN SINTESIS}

\section{A. Pengaruh Agribisnis Terhadap Pemerataan Pembangunan Di kabupaten Buru}

Sektor pertanian mempunyai peranan penting dalam perekonomian Indonesia umumnya dan Kabupaten Buru pada khususnya. Peranan sector pertanian ini dapat dilihat dari kontribusinya pada PDRB Kabupaten Buru yaitu sebesar 35,13 persen di tahun 2014,dengan penyerapan tenaga kerja yang relatif cukup besar dibandingkan dengan sector lainya (Buru dalam angka 2015).

Peranan agribisnis sektor pertanian misalnya dalam penyediaan bahan pangan. Ketersediaan berbagai ragam dan kualitas pangan dalam jumlah pada waktu dan tempat yang terjangkau masyarakat merupakan prasyarat penting bagi keberhasilan pem-bangunan di Kabupaten Buru. Sejarah modern menunjukkan bahwa krisis pangan secara langsung mempengaruhi kondisi sosial, politik, dan keamanan nasional, secarah otomatis hal ini pun berpengaruh pada wilayah Kabupaten Buru yang juga merupakan kabupaten penyuplai beras terbesar di propinsi Maluku. Pada dasarnya tidak perlu diragukan lagi, bahwa pembangunan ekonomi yang berbasiskan kepada sektor pertanian (agribisnis), telah memberikan bukti dan peranan yang cukup besar dalam pembangunan perekonomian, dan tentunya lebih dari itu.

Contoh kasus: Manfaat pembangunan sistem agribisnis dalam meningkatkan pertumbuhan dan pemerataan perekonomian adalah.

1) Banyak melibatkan tenaga kerja karena sistem agribisnis menggunakan sumberdaya alam yang ada yang dapat diperbaharui serta lebih banyak tenaga kerja yang dilibatkan baik yang berpendidikan maupun yang tidak berpendidikan.

2) Mampu meningkatkan efisiensi sektor pertanian hingga hingga menjadi kegiatan yang sangat produktif melalui proses modernisasi pertanian.

3) Agribisnis merupakan penyumbang terbesar dalam PDRB non-migas.

4) Mampu meningkatkan ketahanan dan keamanan bahan pangan.

5) Mewujudkan pemerataan hasil pembangunan. Untuk mewujudkan pemerataan di Kabupaten Buru perlu digunakan teknologi produksi output 
yang banyak menggunakan sumberdaya tersebut. Melalui pembangunan agribisnis, yang sumberdayanya tersebar di dikabupaten buru, diharapkan mampu melibatkan partisipasi seluruh masarakat dan Pemerentah Daerah sekaligus ikut menikmati outputnya melalui pendapatan yang diperoleh dari pembayaran faktor produksi.

Kendala atau hambatan dalam membangun agribisnis di Kabupaten Buru adalah:

1. Iklim tidak bisa dikendalikan sehingga perlu membangun strategi dalam membangun agribisnis.

2. Kurangnya modal bagi para pelaku agribisnis.

3. Infrastruktur yang belum berkembang dengan baik sehingga menghambat distribusi dalam pemasaran.

4. Kurangnya pendampingan agribisnis bagi para pelakunya secara profesional.

5. Kurangnya partisipasi masyarakat dalam membangun agribisnis dan minimnya pengetahuan dalam pengembangan agribisnis sebagai pelaku utama.

Upaya konkrit yang perlu dilakukan untuk menghadapi kendala tersebut adalah:

1. Melakukan penelitian dan mencari strategi dengan teknologi yang tepat dalam mengantisipasi iklim yang terjadi.

2. Adanya kebijakan pemerintah Daerah bagi dunia perbankan untuk memudahkan permodalan bagi para pelaku agribisnis.

3. Membangun dan membenahi infrastruktur khususnya di pedesaan yang menunjang kegiatan agribisnis.

4. Melakukan pendampingan agribisnis kepada pelaku utama secara profesional dan berkelanjutan.

5. Memberikan pendidikan dan pelatihan mengenai keuntungan agribisnis kepada pelaku utama.

B. Peran Agribisnis Dalam Pemerataan Pembangunan di Kabupaten Buru. 
Ada beberapa aspek yang dapat ditempuh dalam upaya mengembangkan kegiatan agribisnis diantaranya :Pembangunan Agribisnis merupakan pembangunan industri dan pertanian serta jasa yang dilakukan sekaligus, dilakukan secara simultan dan harmonis. Peningkatan produksi pertanian kabupaten buru yang begitu besar tidak diikuti oleh perkembangan industri pengolahan (Membangun industri berbasis sumberdaya domestik/lokal). Sehingga perlu pengembangan Agribisnis Vertikal.

Membangun Agribisnis adalah membangun keunggulan bersaing diatas keunggulan komparatif. Dalam arti bahwa membangun daya saing produk agribisnis melalui transformasi keunggulan komparatif menjadi keunggulan bersaing, yaitu dengan cara: Mengembangkan subsistem hulu (pembibitan, agro-otomotif, agro-kimia) dan pengembangan subsistem hilir yaitu pendalaman industri pengolahan ke lebih hilir dan membangun jaringan pemasaran secara nasional dan internasional, sehingga pada tahap ini produk akhir yang dihasilkan sistem agribisnis didominasi oleh produk-produk lanjutan atau bersifat capital and skill labor intensive.

Pembangunan sistem agribisnis yang digerakkan oleh kekuatan inovasi. Dengan demikian produk utama dari sistem agribisnis pada tahap ini merupakan produk bersifat Technology intensive and knowledge based. Perlu orientasi baru dalam pengelolaan sistem agribisnis yang selama ini hanya pada peningkatan produksi harus diubah pada peningkatan nilai tambah sesuai dengan permintaan pasar serta harus selalu mampu merespon perubahan selera konsumen secara efisien.

1. Menggerakkan kelima subsistem agribisnis secara simultan, serentak dan harmonis.

Untuk menggerakkan Sistem agribisnis perlu dukungan semua pihak yang berkaitan dengan agribisnis/ pelaku-pelaku agribisnis mulai dari Petani, Koperasi, Pemerintah Daerah dan swasta serta perlu seorang Dirigent yang mengkoordinasi keharmonisan Sistem Agribisnis. 
2. Menjadikan Agroindustri sebagai A Leading Sector.

Agroindustri adalah industri yang memiliki keterkaitan ekonomi (baik langsung maupun tidak langsung) yang kuat dengan komoditas pertanian. Keterkaitan langsung mencakup hubungan komoditas pertanian sebagai bahan baku (input) bagi kegiatan agroindustri maupun kegiatan pemasaran dan perdagangan yang memasarkan produk akhir agroindustri. Sedangkan keterkaitan tidak langsung berupa kegiatan ekonomi lain yang menyediakan bahan baku (input) lain diluar komoditas pertanian, seperti bahan kimia, bahan kemasan, dll. Dalam mengembangkan agroindustri, tidak akan berhasil tanpa didukung oleh agroindustri penunjang lain seperti industri pupuk, industri pestisida, industri bibit/benih, industri pengadaan alat-alat produksi pertanian dan pengolahan agroindustri seperti industri mesin perontok dan industri mesin pengolah lain.

3. Membangun Sistem agribisnis melalui Industri Perbenihan

Industri Perbenihan merupakan mata rantai terpenting dalam pembentukan atribut produk agribisnis secara keseluruhan. Atribut dasar dari produk agribisnis seperti atribut nutrisi (kandungan zat-zat nutrisi) dan atribut nilai (ukuran, penampakan, rasa, aroma dan sebagainya) serta atribut keamanan dari produk bahan pangan seperti kandungan logam berat, residu pestisida, kandungan racun juga ditentukan pada industri perbenihan. Oleh karena itu Pemda perlu mengembangkan usaha perbenihan (benih komersial) berdasar komoditas unggulan masingmasing daerah, yang selanjutnya dapat dikembangkan menjadi industri perbenihan modern.

4. Dukungan Industri Agro-otomotif dalam pengembangan sistem agribisnis Perlu adanya rental Agro-otomotif yang dilakukan oleh Koperasi Petani atau perusahaan agro-otomotif itu sendiri.

5. Dukungan Industri Pupuk dalam pengembangan sistem agribisnis.

Pada waktu yang akan datang industri pupuk perlu mengembangkan sistem Networking baik vertikal (dari hulu ke hilir) maupun Horisontal (sesama perusahaan pupuk), yaitu dengan cara penghapusan 
penggabungan perusahaan pupuk menjadi satu dimana yang sekarang terjadi adalah perusahaan terpusat pada satu perusahaan pupuk pemerintah. Oleh karena perusahaan-perusahaan pupuk harus dibiarkan secara mandiri sesuai dengan bisnis intinya dan bersaing satu sama lain dalam mengembangkan usahanya. Sehingga terjadi harmonisasi integrasi dalam sistem agribisnis. Serta perlu dikembangkan pupuk majemuk, bukan pupuk tunggal yang selama ini dikembangkan.

6. Pengembangan Sistem Agribisnis melalui Reposisi Koperasi Agribisnis. Koperasi perlu mereformasi diri agar lebih fokus pada kegiatan usahanya terutama menjadi koperasi pertanian dan mengembangkan kegiatan usahanya sebagai koperasi agribisnis. Untuk memperoleh citra positif layaknya sebuah koperasi usaha misalnya: Koperasi Agribisnis atau Koperasi Agroindustri atau Koperasi Agroniaga yang menangani kegiatan usaha mulai dari hulu sampai ke hilir.

7. Pengembangan Sistem Agribisnis melalui pengembangan sistem informasi agribisnis.

Dalam membangun sistem informasi agribisnis, ada beberapa aspek yang perlu diperhatikan adalah informasi produksi, informasi proses, distribusi, dan informasi pengolahan serta informasi pasar.

8. Membumikan pembangunan sistem Agribisnis dalam otonomi daerah Pembangunan Ekonomi Desentralistis-Bottom-up, yang mengandalkan industri berbasis Sumberdaya lokal. Pembangunan ekonomi Daerah akan terjadi di setiap Desa.

9. Dukungan perbankan dalam pengembangan sistem agribisnis di desa. Untuk membangun agribisnis di daerah, peranan perbankan sebagai lembaga pembiayaan memegang peranan penting. Ketersediaan skim pembiayaan dari perbankan akan sangat menentukan maju mundurnya agribisnis daerah. Selama ini yang terjadi adalah sangat kecilnya alokasi kredit perbankan pada agribisnis daerah, khususnya pada on farm agribisnis. 
10. Pengembangan strategi pemasaran

Pengembangan strategi pemasaran menjadi sangat penting peranannya terutama menghadapi masa depan, dimana preferensi konsumen terus mengalami perubahan, keadaan pasar heterogen. Dari hal tersebut, sekarang sudah mulai mengubah paradigma pemasaran menjadi menjual apa yang diinginkan oleh pasar (konsumen).

11. Pengembangan sumberdaya agribisnis.

Dalam pengembangan sektor agribisnis agar dapat menyesuaikan diri terhadap perubahan pasar, diperlukan pengembangan sumberdaya agribisnis, khususnya pemanfaatan dan pengembangan teknologi serta pembangunan kemampuan Sumberdaya Manusia (SDM) Agribisnis sebagai aktor pengembangan agribisnis.

12. Pengembangan Pusat Pertumbuhan Sektor Agribisnis.

Perlu pengembangan pusat-pusat pertumbuhan sektor agribisnis komoditas unggulan yang didasarkan pada peta perkembangan komoditas agribisnis, potensi perkembangan dan kawasan kerjasama ekonomi.

13. Pengembangan Infrastruktur Agribisnis.

Dalam pengembangan pusat pertumbuhan Agribisnis, perlu dukungan pengembangan Infrastruktur seperti jaringan jalan dan transportasi (laut, darat, sungai dan udara), jaringan listrik, air, pelabuhan domestik dan pelabuhan ekspor dan lain-lain.

14. Kebijaksanaan terpadu pengembangan

Ada beberapa bentuk kebijaksanaan terpadu dalam pengembangan agribisnis.

a. Kebijaksanaan pengembangan produksi dan produktivitas ditingkat perusahaan.

b. Kebijaksanaan tingkat sektoral untuk mengembangkan seluruh kegiatan usaha sejenis.

c. Kebijaksanaan pada tingkat sistem agribisnis yang mengatur keterkaitan antara beberapa sektor.

d. Kebijaksanaan ekonomi makro yang mengatur seluruh kegiatan perekonomian yang berpengaruh langsung maupun tidak langsung terhadap agribisnis. 
15. Pengembangan agribisnis berskala kecil.

Ada 3 kebijaksanaan yang harus dilakukan adalah:

a. Farming Reorganization

Reorganisasi jenis kegiatan usaha yang produktif dan diversifikasi usaha yang menyertakan komoditas yang bernilai tinggi serta reorganisasi manajemen usahatani. Dalam hal ini disebabkan karena keterbatasan lahan yang rata-rata kepemilikan hanya $0,1 \mathrm{Ha}$.

b. Small-scale Industrial Modernization

Modernisasi teknologi, modernisasi sistem, organisasi dan manajemen, serta modernisasidalam pola hubungan dan orientasi pasar.

c. Services Rasionalization

Pengembangan layanan agribisnis dengan rasionalisasi lembaga penunjang kegiatan agribisnis untuk menuju pada efisiensi dan daya saing lembaga tersebut. Terutama adalah lembaga keuangan pedesaan, lembaga litbang khususnya penyuluhan.

16. Pembinaan Sumberdaya Manusia untuk mendukung pengembangan agribisnis dan ekonomi

Dalam era Agribisnis, aktor utama pembangunan agribisnis dan aktor pendukung pembangunan agribisnis perlu ada pembinaan kemampuan aspek bisnis, manajerial dan berorganisasi bisnis petani serta peningkatan wawasan agribisnis. Dalam hal ini perlu reorientasi peran penyuluhan pertanian yang merupakan lembaga pembinaan SDM petani. Oleh karena itu perlu peningkatan pendidikan penyuluh baik melalui pendidikan formal, kursus singkat, studi banding. Serta perlu perubahan fungsi BPP yang selama ini sebagai lembaga penyuluhan agro-teknis, menjadi Klinik Konsultasi Agribisnis. 


\section{DAFTAR PUSTAKA}

Arsyad, Lincolin. 1999. Pengantar Perencanaan dan Pembangunan Ekonomi Daerah. BPFE, Yogyakarta.

Glasson, Jhon, 1977. Pengantar Perencanaan Regional: Terjemahan Paul Sitohang, Lembaga Penerbit Fakultas Ekonomi Universitas Indonesia, Jakarta.

Katalog BPS / BPS Catalogue : 1102001.8104

Kuncoro, Mudrajat. 2004. Otonomi dan Pembangunan Daerah: Reformasi, Perencanaan, Strategi dan Peluang. Erlangga, Jakarta.

Kuznets Jhingan 2000 Teori pertumbuhan ekonomi.

Saragih, bungaran, siswono Yudo Husodo,. 2005. Pertanian Mandiri. Penebar swadaya, Jakarta.

Saragih, bungaran. Refleksi Agribisnis. IPB Bogor.

Sos, M. C. B. U. S., \& Si, M. POSTMODERNISME DALAM PANDANGAN JEAN FRANCOIS LYOTARD.

Sukirno, Sadono, 1985. Ekonomi Pembangunan: Proses, Masalah dan dasar Kebijakan, LPFE-UI, Jakarta.

Tambunan, Tulus T. H, 2001. Transformasi Ekonomi di Indonesia: Teori \& Penemuan Empiris. Salemba Empat Jakarta.

Tarigan, Robinson, 2002. Perencanaan Pembangunan Wilayah: Pendekatan Ekonomi dan Ruang, Direktorat Jenderal Pendidikan Tinggi Departemen Pendidikan Nasional, Medan.

Umanailo, M Chairul Basrun. Teknik Praktis Grounded Theory Dalam Penelitian Kualitatif. April 2018. https://doi.org/10.13140/RG.2.2.18448.71689

Umanailo, $\mathrm{M}$ Chairul Basrun. Agama Dalam Identitas. https://doi.org/10.13140/RG.2.2.34980.99202

Umanailo, M Chairul Basrun. Dominasi Modal Ekonomi Atas Ranah Politik. https://doi.org/10.13140/RG.2.2.21873.79207

Umanailo, M Chairul Konsumerisme. https://doi.org//10.13140/RG.2.2.31101.26084

Umanailo, M Chairul Basrun. Mengurai Kekerasan Simbolik di Sekolah Sebuah Pemikiran Pierre Bourdiue Tentang Habitus Dalam Pendidikan. https://doi.org//10.13140/RG.2.2.24809.80483

Umanailo, M Chairul Basrun. Perubahan Sosial di Indonesia:Tradisi Akomodasi dan Modernisasi. March 2018. https://doi.org/10.13140/RG.2.2.23761.22887/1

Umanailo, M Chairul Basrun. Postmodernisme Dalam Pandangan Jean Francois Lyotard. March 2018. https://doi.org/10.13140/RG.2.2.20300.92802

Umanailo, M Chairul Basrun. Proses Modernisasi dan Pergeseran Okupasi. March 2018. https://doi.org/10.13140/RG.2.2.19671.78241

Umanailo, M Chairul Basrun. Teknik Praktis Riset Fenomenologi. March 2018. https://doi.org/110.13140/RG.2.2.19320.34563

Umanailo, M. (2018). Chairul Basrun. 2018. Perubahan Sosial di Indonesia.

Umanailo, M. C. B. (2017). Adakah Ukuran Kemiskinan Buat Masyarakat Di Kabupaten Buru?.

Umanailo, M. C. B. (2017). Eksistensi Waranggana Dalam Ritual Tayub.

Umanailo, M. C. B. (2017). KAJIAN DAN ANALISIS SOSIOLOGI. Open Science Framework. December, 11.

Umanailo, M. C. B. (2017). Keterbatasan Penggunaan Teknologi Informasi Pada Pelayanan Dan Pembelajaran Di Universitas lqra Buru.

Umanailo, M. C. B. (2017). Keterlekatan Petani Dan Transaksi Non Tunai Dalam Pemasaran Hasil Pertanian.

Umanailo, M. C. B. (2017). MARGINALISASI BURUH TANI AKIBAT ALIH FUNGSI LAHAN. Open Science Framework. December, 11.

Umanailo, M. C. B. (2017). MASYARAKAT BURU DALAM PERSPEKTIF KONTEMPORER. Open Science Framework. December, 10. 
Umanailo, M. C. B. (2017, December 11). SOSIOLOGI HUKUM. https://doi.org/10.17605/OSF.IO/KHFNU

Umanailo, M. C. B. (2018, April 1). KONSUMERISME MENUJU KONSTRUKSI MASYARAKAT MODERN. https://doi.org/10.17605/OSF.IO/U8SED

Umanailo, M. C. B. (2018, March 21). Kalesang Desa dalam Konteks Membangun dari Desa. https://doi.org/10.17605/OSF.IO/MSZCK

Umanailo, M. C. B. (2018, March 30). Desa Sebagai Poros Pembangunan Daerah. https://doi.org/10.17605/OSF.IO/7XWBJ

Umanailo, M. C. B., Hentihu, I., Nawawi, M., Bula, M., Hamid, I., Ningkeula, E. S., ... \& Jumu, L. (2018). Naskah Akademik Pedoman Teknis Peraturan Desa.

Umanailo, M. C. B., Sos, S., \& Si, M. (2018). Ilmu Sosial Budaya Dasar. Open Science Framework. March, 17.

Umanailo, M. C. B., Sos, S., \& Si, M. PROSES MODERNISASI DAN PERGESERAN OKUPASI.

Umanailo, M. C., Hentihu, I., Nawawi, M., Bula, M., Hamid, I., Ningkeula, E. S., \& Umanailo, R. La Jumu 2018.". NASKAH AKADEMIK PERLINDUNGAN LAHAN PERTANIAN PANGAN BERKELANJUTAN”. LawArXiv. February, 28. 
